\title{
Disposal of animal healthcare services waste in southern Brazil: One Health at risk
}

\author{
Descarte de resíduos de serviços de saúde animal no sul do Brasil: \\ Saúde Única em risco
}

Kelly Scherer de Oliveira', Larissa Morello', Simone Vassem de Oliveira', Lenita Agostinetto', Bruna Fernanda da Silva', Ana Emilia Siegloch'

DOI: $10.1590 / 0103-110420195306$

\begin{abstract}
Brazilian animal livestock is in full expansion but linked to the use of veterinary drugs which may be considered as emerging contaminants. The study aimed to characterize the disposal of Animal Healthcare Service Waste (AHSW), especially of veterinary drugs, besides identifying the most used drugs in the city of São Joaquim municipality, southern Brazil. Eighty-four cattle ranchers were interviewed through a structured questionnaire with closed questions about drugs use and disposal of the AHSW. The active ingredients of drugs most used were the antiparasitic ivermectin (68\% of properties) and the antimicrobial oxytetracycline (48\%). After the use, the disposal of the AHSW, including expired drugs, leftovers and wrapper, was the disposal next to the domestic trash, burned and deposited in the soil. The Chi square test showed association between the age of the participants and the disposal of sharp objects $\left(X^{2}=36,36, p=0,020\right)$, showing that farmers aged above 60 years usually reuse, the ones who are 20 years old return to the place where they acquired the material and the rest adopts improper practices. The disposal practices of the AHSW adopted in the properties are still in disagreement with the current Brazilian legislation and may cause adverse effects on human, animal and environmental health.
\end{abstract}

KEYWORDS Waste management. Medical waste. Veterinary drugs. Public health.

RESUMO A pecuária brasileira está em franca expansão, porém associada ao uso de medicamentos veterinários que podem ser considerados contaminantes emergentes. Este estudo objetivou caracterizar o descarte dos Resíduos de Serviços de Saúde Animal (RSSA), especialmente dos medicamentos veterinários, além de identificar os medicamentos mais usados no município de São Joaquim, Sul do Brasil. Foram entrevistados 84 criadores de gado por meio de questionário estruturado com questões fechadas sobre uso de medicamentos e descarte dos RSSA. Os princípios ativos de medicamentos mais usados foram o antiparasitário ivermectina (68\% das propriedades) e o antimicrobiano oxitetraciclina (48\%). Após o uso, o descarte dos RSSA foi no resíduo domiciliar, queimado e a depositado no solo. $O$ teste Qui quadrado mostrou associação entre a idade dos participantes e o descarte de perfurocortantes $\left(X^{2}=36,36, p=0,020\right)$, evidenciando que agricultores com idade acima de 60 anos costumam reutilizar, aqueles com idade abaixo de 20 anos devolvem no local onde adquirem o material e os demais adotam práticas inadequadas para o descarte. As práticas de descarte dos RSSA

1 Universidade do Planalto Catarinense (Uniplac), Programa de PósGraduação em Ambiente e Saúde (PPGAS) - Lages (SC), Brasil. asiegloch@gmail.com adotadas nas propriedades rurais estão em desacordo com a legislação brasileira vigente e podem ocasionar efeitos adversos na saúde humana, animal e ambiental.

PALAVRAS-CHAVE Gerenciamento de resíduos. Resíduos de serviços de saúde. Drogas veterinárias. Saúde pública. 


\section{Introduction}

One of the wastes generated in animal production are the ones of the animal healthcare service, composed of plastic, paper, glass, cardboard, sharp objects, chemical or biological residue $^{\mathbf{1}}$. Of these, veterinary drugs that play an important role in the production of animal protein are emphasized, guaranteeing food for millions of people, and the class of antimicrobials is one of the most used in agriculture worldwide $^{2}$. The increasing production of animal protein in an intensive system ${ }^{3}$ and lack of clear laws and regulations on the use of antimicrobials has generated an often-irrational increase in antimicrobial consumption ${ }^{4}$. Among the countries with the highest consumption of antimicrobials to produce food of animal origin are China (23\%), the United States (13\%) and Brazil (9\%), which indicates the potential contribution of these countries to the global load of antimicrobial resistance ${ }^{4}$. The excessive and subtherapeutic antimicrobials doses used in animal production and inappropriate waste disposal of animal healthcare services contribute to disseminate drug resistant pathogens, both in animals and in humans, posing a significant threat to public health $\mathbf{1 , 4}$.

Currently, the concept of One Health has been recommended as an effective approach to solve complex health problems involving multiple disciplines, representing an integrated vision of health, composed of three inseparable areas: human, animal and environmental ${ }^{3}$. Thus, One Health could be used to implement programs, policies, legislation and research in which multiple professional work together to achieve better public health outcomes, especially in the areas of food safety, control of zoonoses (diseases that can spread among humans and animals) and reduction of antibiotic resistance, that happens when bacteria change after exposed to antibiotics, making treatment difficult ${ }^{4,5}$. Moreover, incorporating a One Health approach into public health policy is widely expected to increase efficiency and cost-effectiveness by minimize the overlap between human, animal and environmental health services ${ }^{6}$.

The main routes of entry of veterinary drugs into the environment are through urine and feces excreta from medicated animals, which contains metabolites of pharmaceuticals, soil fertilization consisting of animal waste, improper disposal of packaging, sharp objects, disposal of leftover and expired drugs in the urban solid waste collection network and direct release into the water of drugs used in aquaculture ${ }^{7-9}$.

Among the emerging pollutants, drug wastes pose a serious threat to human health and to environmental integrity ${ }^{\mathbf{1 0}}$, with studies already detecting drugs in sewage, treated wastewater ${ }^{7,11}$, surface waters of rivers ${ }^{11,12}$, river sediment ${ }^{13}$, drinking water for the human population ${ }^{14}$, and marine ecosystems ${ }^{15}$.

Pharmaceutical wastes found in increasing concentrations in the surface water of rivers for human consumption and effluents when not efficiently removed by treatment plants may cause serious toxic effects on human health ${ }^{10}$. Data from a study conducted by Locatelli, Sodré, Jardim ${ }^{\mathbf{1 2}}$ along the Atibaia river, an important water resource in Campinas, southeastern Brazil, evidenced about seven antimicrobials in water (penicillin, fluoroquinolone, sulfonamide, tetracycline, cephalosporin and diaminopyrimidine).

In Brazil, the National Solid Waste Policy (PNRS), represented a major advance for waste management, since it defined the classification of waste according to origin and as to hazardousness, by framing the drugs in the class of healthcare service waste, in addition to stimulating reverse logistics ${ }^{\mathbf{1 6}}$. However, the PNRS does not provide for specific regulations for proper disposal of animal healthcare service waste, including expired drugs and veterinary treatment waste. The current National Health Surveillance Agency's Resolution (RDC $\mathrm{n}^{\circ} 222 / 2018$ ), also does not have a clear and accessible wording on the disposal of the animal healthcare service waste, and there is still no mechanism for verifying the application of reverse logistics for the collection of unused 
or expired veterinary drugs $\mathbf{1 7 , 1 8}$. There are only occasional programs of reverse logistics of human healthcare services waste in some states and municipalities, and such initiatives are still incipient and focused only on medicinal products for human use in urban areas and for healthcare facilities, they do not include the disposal of these wastes in the rural area nor veterinary medicinal products. In the present study the expression Animal Healthcare Service Waste (AHSW) was adopted to address the type of waste researched.

Data on the practices adopted for the AHSW disposal, especially veterinary drugs in rural areas, are still incipient in Brazil1,19. The existing data refer to the disposal of medicinal products for human use, where it has been reported that the population disposes of drugs inappropriately, such as in the domestic trash, in the recyclable waste, in the toilet and sink, in addition, the population does not know about the current legislation and about the places of collection of these wastes, campaigns or public announcements that disclose their correct disposal ${ }^{20}$.

Therefore, it is necessary for the interdisciplinary and integrated action of the scientific community, cattle ranchers and regulatory authorities, veterinarians, physicians, to minimize the problems of environmental, human and animal contamination by veterinary drugs $^{8}$, according to One Health assumptions. With this scenario in mind, this study aimed to know the practices adopted for the disposal of animal healthcare services waste, especially veterinary drugs (expired, leftovers and packaging) generated in the sanitary management of cattle on rural properties in southern Brazil, in addition to identify the most commonly used drugs in these properties.

\section{Material and methods}

This study evaluated the ways of disposing of animal healthcare service waste, especially veterinary drugs by means of a descriptive approach and quantitative method, with data collection through interviews with farmers who raise cattle and field observations. This study was approved by the Research Ethics Committee of the Planalto Catarinense University $\left(\mathrm{n}^{\mathrm{0}} 1,949,980\right)$.

Two rural areas were selected for convenience and accessibility in the municipality of São Joaquim, located in the state of Santa Catarina (2818'19”'S, 4956'41”W), Brazil. According to the Köppen classification, the climate is $\mathrm{Cfb}$, in other words, temperate humid, with temperate summer, without dry season, and the average annual temperature is $13.5^{\circ}$.

About 30\% (6,183 inhabitants) of the municipality's population live in the rural area ${ }^{\mathbf{2 1}}$, the local economy being sustained in animal husbandry and characterized by beef cattle ranching, however, it had a great economic boost with the apple cultivation, which began in the 1970s. According to the latest Brazilian agricultural census published in 2017, São Joaquim has an estimated population of 55,025 heads of cattle, being considered the fifth largest cattle herd in the state ${ }^{\mathbf{2 2}}$.

Data collection was carried out between August and November 2017 with 84 rural farmers responsible for property management. The data collection instrument was a structured questionnaire with closed questions in a multiple-choice format, applied in the form of interviews with farmers. The collection instrument was developed to obtain information on: sociodemographic data of farmers; use of veterinary drugs, use of personal protective equipment; disposal of drug waste (leftovers, expired and packaging). In addition to the interview, a field observation was carried out, using a standardized script, where the types of inputs most used in rural properties were observed, such as syringes, needles, scalpel blade, gloves, serum bottles and drugs (antibiotics, anesthetics, analgesics, anti-inflammatories, hormones, antiparasitics, repellents, healing ointments, among others) and the form of storage and disposal of the wastes.

The participants were approached in their properties, and in the first moment, the 
objectives of the study and the reading of the informed consent term were presented. After the agreement and signing of the term, data collection lasted an average of 40 minutes.

In this study, the following inclusion criteria of the participant were adopted: the signing of the term; to be over 18 years of age; to own a property in one of the two selected locations, regardless of the number of heads of cattle and their use (for milk, cut or both).

After the organization of the database, they were submitted to descriptive statistical procedures (mean, percentage and standard deviation) and the results were presented in graphs and tables. A chi-squared test $\left(\chi^{2}\right)$ was also performed in the SPSS software (Statistical Package for the Social Sciences, version 20) to verify the possible association between the variables level of education and age with the forms of disposal of veterinary drug waste. It was used $\mathrm{p} \leq 0.05$ as the criterion for statistical significance.

\section{Results}

\section{Characterization of rural properties and workers}

In this study, data were collected from 84 farmers, of whom $85.4 \%$ were male and $14.6 \%$ female, with a mean age of $49(\mathrm{SD} \pm 15)$ years. The highest percentage of workers presented age between 41 and 60 years, followed by the age group above 60 years of age and between 21 and 40 years old (29.3\% in both). Moreover, the population was represented by a low number of workers aged between 18 and 20 years (2.4\%). Regarding level of education, most farmers (45.8\%) have incomplete primary education, followed by those with full secondary education (18.1\%). Only $3.8 \%$ of the population has technical education, $5.7 \%$ higher education.

About $90 \%$ of rural workers have their own land and their own cattle and only $4 \%$ are tenants. Of the farmers, $92 \%$ use family labor force and have a mean of three people ( $\mathrm{DP} \pm 2$ people). The properties of the study were distinct in size ranging from 2.5 to 475 ha. Cattle ranching was considered extensive in $96 \%$ of the properties. In the study area, a herd of 1,892 heads of cattle was counted, which represent $3.44 \%$ of the herd of the municipality.

\section{Use of veterinary drugs in rural properties}

Most of the study participants (72.8\%) reported not having technical assistance, they only search for veterinarians and agricultural establishments when there is a need to diagnose and treat some disease in the herd. When questioned about where to obtain instructions for purchase and use of veterinary drugs, $62.3 \%$ seek help in technical assistance, $23.4 \%$ use non-oriented prescription (administer drugs for their own account), 7.4\% by indication of third parties and $4.9 \%$ purchase the drugs based on the information obtained in the package insert.

Most producers (59.8\%) were never instructed on how to store the purchased drugs. After the purchase of the veterinary drugs, $65.8 \%$ of the participants reported keeping them in the shed with other inputs, $20.3 \%$ in their own shelter, $3.8 \%$ reported to store them in the residence refrigerator and 2.5\% in a refrigerator for the drugs. During drug application, $79.0 \%$ of participants do not use any personal protective equipment.

This study showed that antiparasitics (88.0\%), antimicrobials (56.0\%) and vaccines $(54.7 \%)$ were the therapeutic classes with the highest percentage of use among the 84 properties of the study (graph 1). The active ingredients most used by farmers among the antiparasitics were Ivermectin (68.3\%), followed by the synthetic chemotherapeutic that has as its main compound Diaceturate (21.5\%) and Doramectin (17.7\%) (table 1). 
Graph 1. Percentage of use of therapeutic classes in the 84 rural properties studied in the municipality of São Joaquim, SC, Brazil

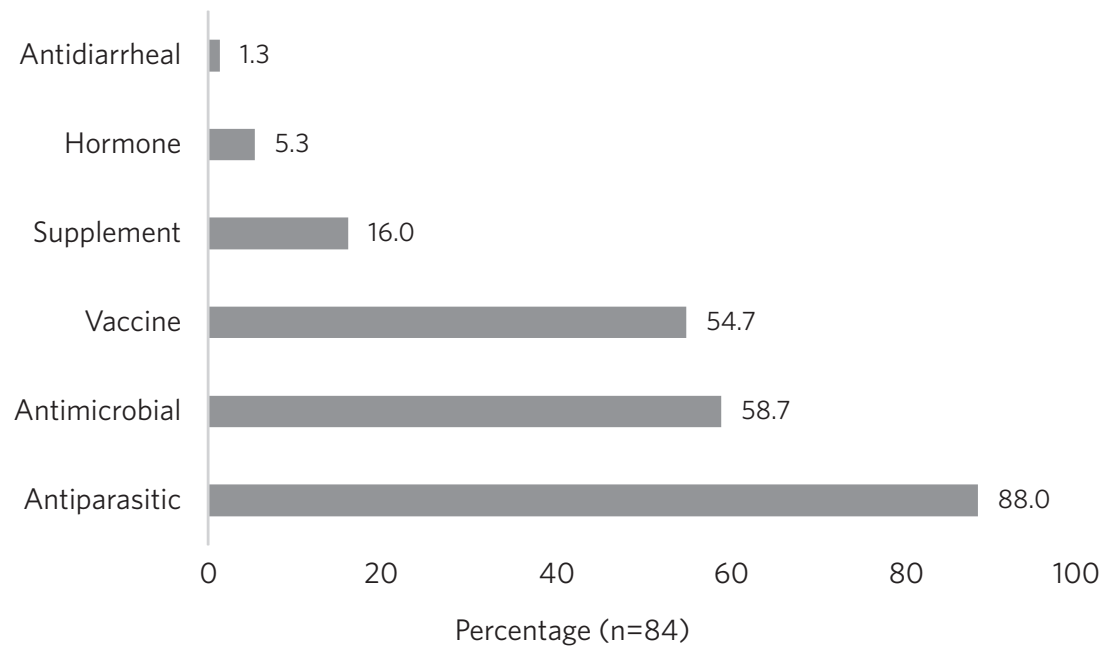

Source: Own elaboration.

Among the antimicrobials, the most used were oxytetracycline (48.0\%), benzylpenicillins $(20.2 \%)$ and dihydrostreptomycins (20.2\%). In third place were the anti-inflammatories represented by piroxicam (24.0\%). Despite being registered at a low percentage in properties, the following active ingredients used in pesticides were found: cypermethrin (acaricide), chlorpyrifos (insecticide), chlorfenvinphos (insecticide), dichlorvos (insecticide), deltamethrin (insecticide), citronellal (insecticide), diflubenzuron (growth regulator), abamectin (insecticide, nematicide) and fipronil (insecticide) (table 1).

Table 1. Prevalence of active ingredients of the drugs used among the rural properties sampled in the municipality of São Joaquim, SC

\begin{tabular}{llr}
\hline Therapeutic Class & Active Ingredient & $\%$ \\
\hline Antiparasitic & Ivermectin & 68.35 \\
Antimicrobial & Oxytetracycline & 48.09 \\
Anti-inflammatory & Piroxicam & 24.05 \\
Antiparasitic & Diazoamino diaceturate dibenzamidine & 21.52 \\
Antimicrobial & Procaine benzylpenicillin & 20.25 \\
Antimicrobial & Streptomycin & 20.25 \\
Anesthetic & Procaine & 18.99 \\
Vaccines/Biological & Bacterial culture & 17.73 \\
Antiparasitic & Doramectin & 17.72 \\
Antiparasitic & Cypermethrin & 10.13 \\
Antiparasitic & Levamisole Phosphate & 8.86 \\
Antiparasitic & Chlorpyrifos & 7.59 \\
Antiparasitic & Citronellal & 6.33 \\
\hline
\end{tabular}




\begin{tabular}{|c|c|c|}
\hline Antiparasitic & Fipronil $^{\star}$ & 3.80 \\
\hline Hormones/Similar & Pituitary posterior lobe extract (oxytocin) & 3.80 \\
\hline Anti-inflammatory & Diclofenac sodium & 2.53 \\
\hline Antiparasitic & Abamectin* & 2.53 \\
\hline Antiparasitic & Imidocarb (dipropionate) & 2.53 \\
\hline Anti-inflammatory & Pyrazolone & 2.53 \\
\hline Antidiarrheal & Sulfacetamide* & 2.53 \\
\hline Antimicrobial & Benzathine benzylpenicillin & 1.27 \\
\hline Antimicrobial & Potassium benzylpenicillin & 1.27 \\
\hline Antimicrobial & Streptomycin & 1.27 \\
\hline Antiparasitic & Diflubenzuron* & 1.27 \\
\hline Antiparasitic & Dichlorvos* & 1.27 \\
\hline Antiparasitic & Albendazole & 1.27 \\
\hline Antiparasitic & Metrifonate & 1.27 \\
\hline Antiparasitic & Deltamethrin $^{\star}$ & 1.27 \\
\hline Antiparasitic & Chlorfenvinphos* & 1.27 \\
\hline Antimicrobial & Sulfadiazine & 1.27 \\
\hline Antiparasitic & Tetramisole & 1.27 \\
\hline Antiparasitic & Imidocarb dipropionate & 1.27 \\
\hline Hormones/Similar & Cloprostenol Sodium & 1.27 \\
\hline Hormones/Similar & Estradiol Cypionate & 1.27 \\
\hline Hormones/Similar & Chlorobutanol & 1.27 \\
\hline Anti-inflammatory & Dipyrone & 1.27 \\
\hline
\end{tabular}

Source: Own elaboration.

*Active ingredients of pesticides of the insecticidal, acaricidal or nematicidal classes.

\section{Disposal of animal healthcare ser- vices waste}

Regarding the disposal of drug waste (leftovers and expired) and empty packaging, $79.7 \%$ of the interviewees revealed that they had never received information to carry out the proper disposal and only $20.3 \%$ had already received some information on how to dispose of packaging in agriculture.

The practices adopted by farmers to dispose of leftovers from post-treatment drugs and expired drugs are presented in graph 2. Drug leftovers after use were reused at another time by $36.2 \%$ of farmers, however, $18.7 \%$ reported that after the application there are no leftovers. Nevertheless, $45 \%$ of the study participants still adopt some inappropriate practice for the disposal of these wastes, such as disposing them with domestic trash, they bury them, donate them to other people, burn or pour them on the sink drain. Expired drugs were disposed in the domestic trash by $21.0 \%$ of the sampled population, $14.4 \%$ were stored in the shed, $11.8 \%$ were returned to the place of purchase or buried (10.5\%) (graph 2). 
Graph 2. Practices adopted by farmers to dispose leftovers and expired drugs in the 84 rural properties of the municipality of São Joaquim, SC

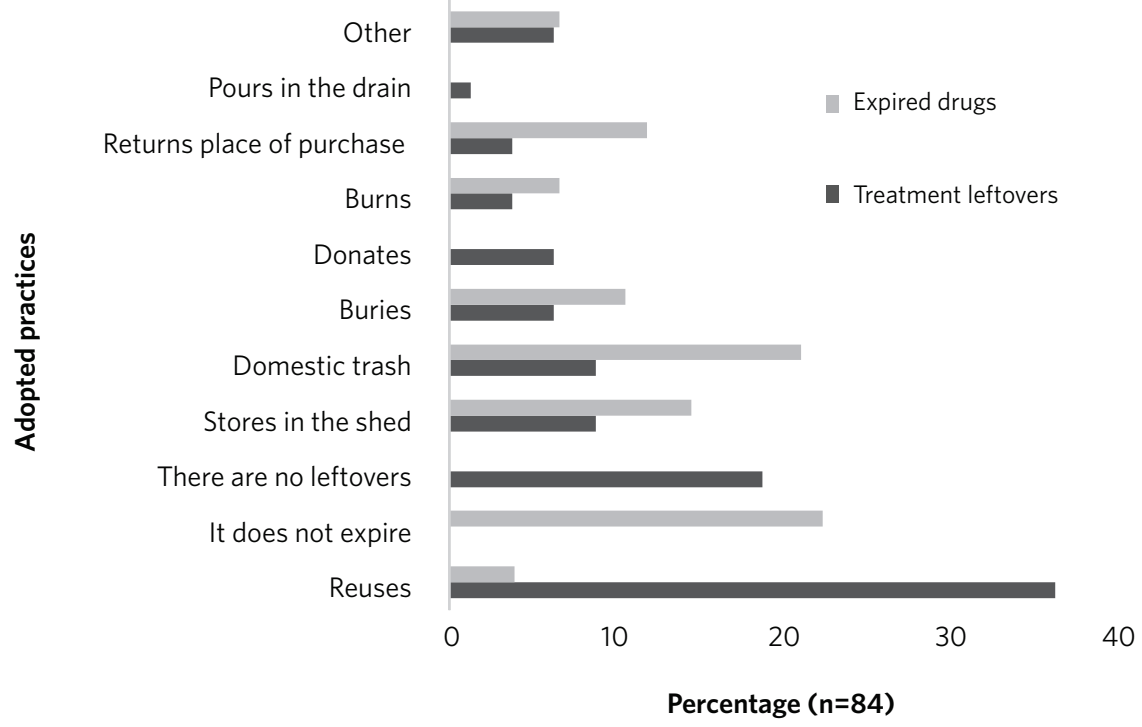

Source: Own elaboration

Regarding the disposal of empty plastic and glass packaging and sharp objects (needles), the highest percentage of farmers reported disposing such waste at home with other wastes (table 2). The data also showed that farmers also tend to bury glass (16.2\%) and sharp items (16.6\%), while the plastic bottles are burned by $25.6 \%$ of the interviewed farmers.

Table 2. Practices adopted for the disposal of glass and plastic packaging and sharp materials of veterinary drugs in the rural properties of the municipality of São Joaquim, SC

\begin{tabular}{lrrr}
\hline Adopted Practices & Glass (\%) & Plastic (\%) & Piercing objects (\%) \\
\hline Domestic trash & 37.84 & 31.08 & 29.17 \\
Buries & 16.22 & 12.16 & 16.67 \\
Stores in the Shed & 13.51 & 8.11 & 5.56 \\
Burns & 9.46 & 25.68 & 4.17 \\
Returns to the place of purchase & 8.11 & 9.46 & 4.17 \\
Returns with pesticide packaging & 8.11 & 6.76 & 0.00 \\
Recyclable solid waste & 2.70 & 2.70 & - \\
Puts in the Daub house & - & - & 12.50 \\
Septic tank & 1.35 & 1.35 & - \\
Stores & & - & 12.50 \\
Reuses & & 9.70 \\
Other & 0.00 & 0.00 & 4.17 \\
\hline Source: Own elaboration & 2.63 & 2.63 &
\end{tabular}

Source: Own elaboration. 
In figure 1, there is a summary of the types of drug waste generated in the rural properties, the practices adopted for the disposal of the waste and the possible routes of contamination of the environment.

Figure 1. Waste disposal routes of veterinary drugs in rural areas. The boxes in blue show the percentage of the main practices adopted by the farmers to dispose the waste.

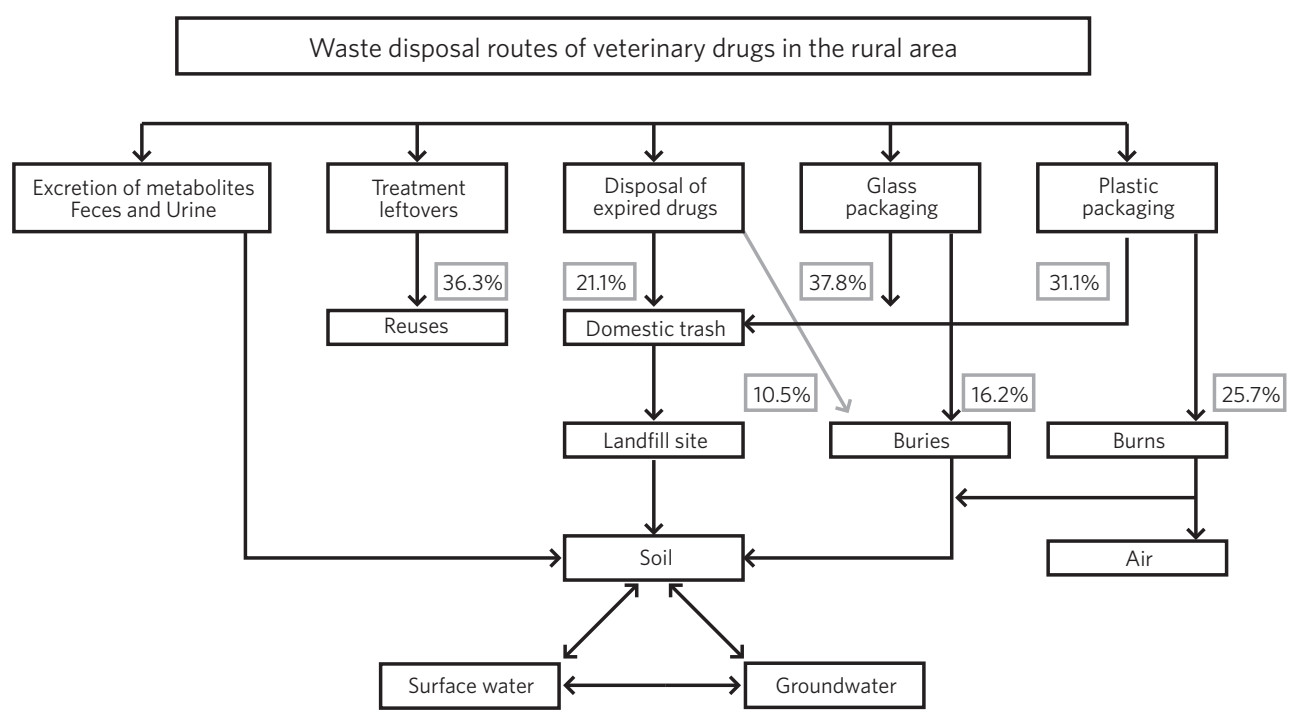

Source: Own elaboration.

The variables related to level of education and age of the farmers were associated with the data obtained of the waste disposal of veterinary drugs. The chi-squared test showed a significant association $\left(\mathrm{X}^{2}=36.36, \mathrm{p}=0.02\right)$ between the age and the disposal of sharp objects, showing that farmers over 60 years old tend to reuse these objects, those in the age group of 41 to 60 years old burn the material, between 21 and 40 years dispose them in the domestic trash that is collected by the prefecture of the municipality and the farmers under the age of 20 years return the sharp objects to the place where they acquire the material.

There was also a significant association between the level of education and the way of obtaining instructions for the purchase and use of drugs $\left(X^{2}=35.39, p=0.026\right)$. The analysis showed that farmers with incomplete higher education usually make the acquisition and application of the drugs through the information contained in the package insert, while those with complete higher education make non-oriented prescription.

\section{Discussion}

\section{Characterization of rural properties and workers}

Aging and low level of education of rural farmers, in addition to the predominance of the male worker evidenced in this study seems to reflect a reality of agriculture. Similarly, the 
synthesis of social indicators of the Brazilian Institute of Geography and Statistics (IBGE) of 2017, when comparing sectors of Brazilian society, draws attention to the higher concentration of workers with the lowest level of education in agriculture, construction and domestic services 22 .

The low level of education added to the fact that $72.8 \%$ of the farmers do not have technical assistance evidences a worrying reality of the agriculture in the region of study. The unavailability of veterinary healthcare services to farmers and the lack of knowledge about the correct use of drugs may stimulate the use of over or sub-doses of drugs, generate difficulties to follow the instructions prescribed in the package insert and favor the suspension of the treatment before the end, which may cause adverse effects to the treatment of diseases ${ }^{2}$. The authors Manyi-Loh et al. ${ }^{2}$ also report that many farmers with this profile rely on knowledge and advice from more experienced farmers and drug sellers.

The predominance of small farms managed by family labor in the study region (92\%) was similar to that of the IBGE census (2006) for the southern region of Brazil, where $84 \%$ of agricultural establishments belong to the sphere of family farmers ${ }^{23}$. In the south of the Country, young farmers have migrated to cities in search of better education, a decision based on the reduced amount of land left to their children and low financial profitability, which hampers the modernization of properties and limits family leisure options ${ }^{\mathbf{2 4}}$. Thus, the absence of successors in family agriculture in southern Brazil has generated uncertainties in the continuity of productive activities of rural families ${ }^{25}$.

Ribeiro et al. ${ }^{26}$ emphasizes the importance of valorization and modernization of the Brazilian rural environment. According to the author, the current model of rural property is still centered on the conventional and conservative model. Hence, the properties of this study need to seek the concept of sustainable territorial development that aims to reduce the barriers between the rural and urban worlds through eco-development, social equity and appreciation of the workforce of family agriculture.

\section{Use of veterinary drugs in rural properties}

Among veterinary drugs, antiparasitics, especially the active ingredients ivermectin and doramectin, were the most used by farmers in this study. Ivermectin and doramectin, derivatives of avermectin, are among the most commonly used antiparasitics for the control of endoparasites and ectoparasites, however, their waste produces adverse effects on the environment, since their waste is ecotoxicological and affects different trophic levels, since it persists in the soil between 14 and 217 days 8,27 .

The indiscriminate use and overdosage of antiparasitics in cattle ranching may lead to the spread of diseases among animals, undesired occurrence of residues in products from treated animals and resistance to active ingredients, posing a risk to human health ${ }^{\mathbf{2 8}}$. In a study conducted by Souza et al. ${ }^{29}$, on the resistance of the helminths of cattle of the Plateau of Santa Catarina to anthelmintics, evidenced resistance of the gastrointestinal parasites of the genera haemonchus, cooperia, ostertagia and trichostrongylus to the use of ivermectin, to levamisole phosphate and to albendazole sulfoxide.

Another active ingredient used by the respondents of the present study was the antiparasitic diaceturate administered in cattle for the clinical signs of babesiosis and anaplasmosis. This drug has also been used in a study on the sanitary management of diseases of dairy cattle as a babesicide and successfully used as an alternative treatment of bovine cutaneous papillomatosis ${ }^{30}$.

Of the 22 commercial names of antiparasitics registered in this study, nine (40\%) have an active ingredient similar to that of pesticides. In this case, the chemical exposure of antiparasitics that are equivalent to pesticides, such as organophosphates and pyrethroids, 
cause several adverse effects on the health of rural workers, such as muscle tremors and convulsions, endocrine changes and allergies ${ }^{31}$. According Silva, Moreira and Peres ${ }^{31}$, they state that the risks to the health of the rural worker are associated to the management of these veterinary products in the field, whose disinformation leads the producer not to use the Personal Protective Equipment (PPE) and to disrespect the grace period of each product. Another aggravating factor is that some antiparasitics used in veterinary drugs are not identified and labeled as pesticides ${ }^{27}$.

In the present study, the antiparasitics cypermethrin, chlorpyrifos, citronellal, fipronil, abamectin, sulfacetamine, diflubenzuron, dichlorvos, deltamethrin and chlorfenvinphos were all found, all with active ingredient of pesticides in their formulation. The dossier of the Brazilian Association of Collective Health also alerted health professionals and researchers, as well as representatives of social and environmental organizations, to the fact that veterinary products are subject to a legislation different from that of other pesticides, although they have equivalent functions (e.g., insecticides) and often present the same active ingredient of other pesticides for agricultural use $^{32}$. The Brazilian legislation provides that the registration of pesticides must be evaluated by the interministerial committee composed of the Ministry of Agriculture, Livestock and Food Supply (Mapa), the Ministry of Health and the Ministry of the Environment, since the registration of veterinary pesticides is evaluated only by Mapa, thus, veterinary antiparasitics may have distinct toxicological classification from pesticides, although both have the same active ingredient.

Among antimicrobial class drugs, $\beta$-lactams represented by benzylpenicillin were the most used in the rural properties of this study ( $72 \%$ of the properties). This active ingredient is also called natural penicillin, used mainly for the treatment of mastitis in the dairy herd ${ }^{33}$. Residues of this active ingredient in products of animal origin may lead to allergic reactions in people sensitive to their compounds and may cause hypersensitivity ${ }^{34}$, rashes, urticaria, asthma and even anaphylactic shock ${ }^{32}$. Also, according to Jones ${ }^{35}$, between $5-10 \%$ of the world population is hypersensitive to penicillin, even in low concentrations.

Another antimicrobial widely used by farmers, oxytetracycline, representative of tetracyclines, is used in cattle for disease prevention and treatment and often used as growth promoters ${ }^{36}$. In a study conducted by Olatoie, Ehinmowo ${ }^{37}$, a high oxytetracycline residue index was shown, above the limits allowed in edible bovine products in Nigeria, indicating improper and generalized use of veterinary drugs.

Thus, inappropriate use of antimicrobials and antiparasitics in livestock may favor the presence of residues in foods derived from medicated animals, leading to the development of microbial and parasitic resistance, causing a reduction in the efficacy of these drugs ${ }^{38}$. Antimicrobial resistance is a growing threat to public health $2,39,40$. The use of antimicrobials to restore health or to ensure intensive production in livestock and agriculture promotes the selection of pathogenic bacteria, since most of these antimicrobials are not entirely metabolized, whose residues in the environment can trigger antimicrobial resistance in animals and humans ${ }^{2,39}$. Many antimicrobials widely used in agriculture prescribed to treat production animals have the same mode of action or belong to the same classes as those used for humans ${ }^{2}$.

The control of bacterial resistance requires concomitant action among agriculture, education, health and media sectors ${ }^{39}$. The main areas of studies under the Food and Agriculture Organization of the United Nations (FAO) action plan for the period 2016-2020 on Antimicrobial Resistance (AMR) stand out: the need to deepen knowledge and threats related to AMR, improvements in monitoring and surveillance in agriculture and food, encouragement of good practices in agricultural and food systems, and use of required doses of antimicrobials ${ }^{41}$.

In addition, the One Health principles have emphasized the importance of involving 
multiple disciplines that represent an integrated view of human, animal and environmental health, thus contributing to the problem of antimicrobial resistance ${ }^{3}$. Human, animal, and environmental health are interrelated in such a complex way that the division among them is only didactic, and the goal of one health is to promote, improve and safeguard the well-being and health of humans and animals through close cooperation and collaboration among professionals in the human and animal medical and environment ${ }^{\mathbf{4 2}}$.

In general, to mitigate the indiscriminate use of antimicrobials, without the prescription and guidance of a veterinarian or supervision, it is necessary to improve the guidance to farmers through training courses involving practices of hygiene, biosafety, sanitation, adequate facilities that support a healthy life of animals avoiding the occurrence of diseases or infections, improvements in nutrition, waste management, using vaccines to boost the immune system, as well as vitamins, minerals, plants, prebiotics, probiotics, bactericides and bacteriophages ${ }^{2}$. Moreover, healthcare worker interference should be dynamic including consumer orientation regarding the proper use and disposal of drugs ${ }^{43}$. In addition, the subject of public health and the assumptions of One Health need to be included in the curriculum of undergraduate healthcare courses, including veterinary and human medicine ${ }^{\mathbf{4 2}}$.

\section{Disposal of animal healthcare ser- vices waste}

This study showed that many of the practices adopted for the disposal of AHSW in rural areas are inadequate. The highest percentages of glass, plastic and sharp objects waste were disposed in the domestic trash, while leftovers from treatment drugs were reused (36.2\%), indicating that the acquisition of larger quantities than those prescribed for the treatment is occurring, that the dose administered was not according to the prescription and/or there is a need for fractionation of the marketed drugs. Another worrying datum is the high percentage (82.5\%) of farmers who inappropriately dispose of expired drugs (domestic trash, soil and drain), while only $11.8 \%$ return them to the place where they purchased the pharmacological products.

The results regarding the disposal of waste of veterinary drugs show a worrying panorama of possible environmental contamination. A similar result was also reported in the study conducted by Sekyere ${ }^{44}$, which showed that farmers dispose of their antimicrobial containers in ditches, dumps or directly on the ground. On the other hand, animal healthcare services establishments manage their waste more adequately, closely associated with the regulations and requirements of Brazilian legislation in force with healthcare service providers. According to Amarante et al. ${ }^{19}$, in a study carried out in the Lages, SC, most veterinary clinics (43\%) dispose of drug leftovers as contaminated waste, pet shops (69\%) in specific containers for chemical residues, however, many veterinary hospital professionals (32\%) were unaware of the procedures adopted at the establishment. Moreover, $36 \%$ of individuals who work at clinics return the expired drugs to resellers, $62 \%$ of professional at pet shops store put away in containers for chemical waste and the interviewees of the hospital (48\%) were unaware of the adopted procedures ${ }^{19}$.

In Brazil, due to the lack of sanitary structure of sewage treatment, the occurrence of drugs in the waste, surface and underground water is inevitable. This is evidenced in IBGE $^{45}$ data that showed that only $52.2 \%$ of the Brazilian municipalities have a sewage collection service and $33.5 \%$ of the households are served by a sewage system. The inadequate disposal of drugs, especially in the domestic trash or in the sewage network, may contaminate water and groundwater resources ${ }^{20}$.

The location of the present study is situated on recharge areas of the Guarani Aquifer, considered the second largest aquifer in the world and it represents an important source of fresh water, whose physical characteristics of 
the Botucatu sandstone favor the contamination, mainly by chemical products. Thus, it is necessary to adopt agricultural and management practices that promote the rational use of pesticides and the proper disposal of animal healthcare services waste.

In addition to environmental contamination, improper disposal of these wastes can cause occupational hazards to recyclable waste pickers, as these wastes are composed of various materials including glass, sharp objects and drug leftovers, which may lead to accidents such as cuts, perforations and even non-oriented prescription ${ }^{46}$.

Many of the participants in this study also reported storing their drugs (packaging, expired and leftovers) along with other inputs. Sekyere ${ }^{44}$ points out that unsafe storage practices under suboptimal conditions, vulnerable (in an easily accessible place for use of unauthorized people, including children) and in a location with temperature fluctuations, found on pig farms in an African country, may accelerate the decomposition of drugs, reducing their concentration and effectiveness.

In the present study, the practices adopted by farmers to dispose of waste were the disposal in the domestic trash, in the landfill and burning, which are ways of direct contamination of the environment. Studies carried out in different regions in Brazil also showed that the most common practice for the disposal of expired and drug leftover is in the domestic trash $\mathbf{2 0 , 4 7 , 4 8}$.

The form of disposal of residues of veterinary drugs seems to be explained by the lack of capacities of the sampled population, since $79.7 \%$ of respondents have never received information for the proper disposal of such waste. In addition, the practices adopted for the disposal of sharp objects are associated with the age range of farmers, whose younger participants tend to return this waste to the place where the veterinary inputs were purchased, an adequate form and recommended in current legislation. On the other hand, it was possible to observe that farmers with higher level of education treat animal diseases based on non-oriented prescription.
In general, this study showed that the practices adopted for the use, storage and disposal of animal healthcare service waste, especially veterinary drugs, in the rural area of the southern region of Brazil are being conducted in an inadequate manner, which may lead to environmental contamination and contribute to the load of antimicrobial resistance in the environment, human and animal health.

\section{Conclusions}

The forms adopted for the disposal of animal healthcare services waste on rural properties in a region of southern Brazil disagree with current Brazilian legislation and good production practices, which may have adverse effects on human, animal and environmental health. Although veterinary drugs are essential to produce sanitary quality food, it is necessary to implement improvements in current legislation to include instructions on the proper disposal of their waste (treatment leftovers, expired drugs and empty packaging, sharp objects), implementation of the reverse logistics for veterinary drugs, besides classifying the antiparasitic drugs as active principles of pesticides. In addition, it would be of great value to implement training courses for the actors involved in cattle ranching (rural producers, technicians, veterinarians) to guide them on the application and grace period of the drugs, current legislation, bacterial resistance to antimicrobials and proper management of animal health services waste. The results of this study may also contribute to the discussion on the role of the One Health approach in public health, considering that inadequate disposal of veterinary drugs can cause serious problems in public health.

\section{Acknowledgment}

The authors would like to thank the research projects 'Construindo a sustentabilidade 
da pecuária familiar dos Campos e Matas de Araucária' (CNPq 441396/2017-8) and 'Avaliação de metais pesados em afluentes do rio canoas em área urbana de recarga do Aquífero Guarani' (Fapesc 2015TR1069).

\section{Collaborators}

The authors contributed to distinct activities in the manuscript: Oliveira KS (0000-00029376-4581)* contributed to the planning, data collection, analysis, data interpretation and manuscript writing. Morello L (00000001-6557-1013)* and Oliveira SV (00000002-4717-445X)* also contributed to the planning and data collection of the manuscript. Agostinetto L (0000-0002-0468-883X)*, Silva BF (0000-0002-3513-8072)* and Siegloch AE (0000-0002-4200-8532)* contributed to the planning, analysis, interpretation of data, elaboration of the draft, critical review of the content and approval of the final version of the manuscript.

\section{References}

1. Menin A, Reck C, Pilati, C, et al. Resíduos de serviços de saúde animal e possíveis indicadores de contaminação ambiental em granjas de suínos de Santa Catarina-SC. Vet. Not. 2008; 14(2):41-48.

2. Manyi-Loh C, Mamphweli S, Meyer E, et al. Antibiotic use in agriculture and its consequential resistance in environmental sources: potential public health implications. Mol. [internet]. 2018 [accessed in 2019 Mar 3]; 23(795):1-48. Available in: 10.3390/molecules 23040795 .

3. Xie T, Liu W, Anderson BD, et al. A system dynamics approach to understanding the One Health concept. PLoS ONE. 2017; 12(9):e0184430.
4. Boeckel TPV, Brower C, Gilbert M, et al. Global trends in antimicrobial use in food animals. Proc Natl Acad
Sci U S A. 2015; 112(18):5649-5654.

5. World Health Organization. One Health [internet]. 2017 [accessed in 2019 Aug 12]. Available in: https:// www.who.int/features/qa/one-health/en/.

6. Baum SE, Machalaba C, Daszak, P, et al. Evaluating one health: Are we demonstrating effectiveness? One Health. 2017; (3):5-10.

7. Bila DM, Dezotti M. Fármacos no Meio Ambiente. Quím. Nova. 2003; 26(4):523-530.

8. Oliveira VM, Oliveira R, Amorim MJB, et al. Os medicamentos veterinários no meio ambiente: aplicações e implicações. Captar. 2009; 1(2):183-192.

9. Pereira LA, Jardim ICSF, Fostier AH, et al. Ocorrên- 
cia, comportamento e impactos ambientais provocados pela presença de antimicrobianos veterinários em solos. Quím. Nova. 2012; 35(1):159-169.

10. Bottoni P, Caroli S. Presence of residues and metabolites of pharmaceuticals in environmental compartments, food commodities and workplaces: A review spanning the three-year period $2014-2016$. Microchem. J. 2018; 136(23):2-24.

11. Stumpf M, Ternes TA, Wilken RD, et al. Polar drug residues in sewage and natural waters in the state of Rio de Janeiro, Brazil. Sci. Total Environ. 1999; 225(12):135-141.

12. Locatelli MAF, Sodré FF, Jardim WF. Determination of antibiotics in Brazilian surface waters using liquid chromatography electrospray tandem mass spectrometry. Arch. Environ. Contam. Toxicol. 2011; 60(3):385-393.

13. Beretta M, Britto V, Tavares TM, et al. Occurrence of pharmaceutical and personal care products (PPCPs) in marine sediments in the Todos os Santos Bay and the north coast of Salvador, Bahia, Brazil. J. Soil. Sediment. 2014; 14(7):1278-1286.

14. Sodré FF, Locatelli MAF, Jardim, WF. Occurrence of emerging contaminants in Brazilian drinking waters: a sewage-to-tap issue. Water Air Soil Pollut. 2010; 206(1-4):57-67.

15. Asif MB, Hai FI, Price WE, et al. Impact of Pharmaceutically Active Compounds in Marine Environment on Aquaculture. In: Hai F, Visvanathan C, Boopathy R, editor. Sustainable Aquaculture. Applied Environmental Science and Engineering for a Sustainable Future. USA: Springer International Publishing; 2018. p. 265-299.

16. Brasil. Lei ${ }^{\circ} 12.305$ de 02 de agosto de 2010. Institui a Política Nacional de Resíduos Sólidos. Diário Oficial da União. 2 Aug 2010.

17. Graciani FS, Ferreira GLBV. Descarte de medicamentos: Panorama da logística reversa no Brasil. Espacios. 2014; 35(5):1-11.
18. Agência Nacional de Vigilância Sanitária. RDC no 222 de 28 de março de 2018. Regulamenta as Boas Práticas de Gerenciamento dos Resíduos de Serviços de Saúde e dá outras providências. Diário Oficial da União. 29 de Mar 2018

19. Amarante JAS, Rech TD, Siegloch AE. Avaliação do gerenciamento dos resíduos de medicamentos e demais resíduos de serviços de saúde na Região Serrana de Santa Catarina. Eng. Sanit. Ambient. 2017; 22(2):1-10.

20. Pinto GMF, Silva KR, Pereira KR, et al. Estudo do descarte residencial de medicamentos vencidos na região de Paulínia (SP), Brasil. Eng. Sanit. Ambient. [internet]. 2014 [accessed in 2019 Jul 10]; 19(3):219224. Available in: http://dx.doi.org/10.1590/S141341522014019000000472.

21. Instituto Brasileiro de Geografia e Estatística. Brasil, Grandes Regiões e Unidades da Federação. Rio de Janeiro: IBGE; 2015.

22. Instituto Brasileiro de Geografia e Estatística. Síntese de Indicadores Sociais-SIS. Primeiros resultados. Brasil, Grandes Regiões e Unidades da Federação. Rio de Janeiro: IBGE; 2017.

23. Instituto Brasileiro de Geografia e Estatística. Censo agropecuário 2006: agricultura familiar. Primeiros resultados. Brasil, Grandes Regiões e Unidades da Federação. Rio de Janeiro: IBGE; 2006.

24. Zago N. Migração rural-urbana, juventude e ensino superior. Rev. Bras. Educ. 2016; 21(64):61-78.

25. Mattei LA. importância do sistema familiar de produção no estado de Santa Catarina. Rev. Necat. [internet]. 2016 [accessed in 2018 Apr 10]; 5(9):3-7. Available in: http://stat.necat.incubadora.ufsc.br/index. php/necat/article/view/4170.

26. Ribeiro AC, Andion C, Burigo F. Ação coletiva e coprodução para o desenvolvimento rural: um estudo de caso do Colegiado de Desenvolvimento Territorial da Serra Catarinense. Rev. Adm. Pública. [internet]. 2015 [accessed in 2018 Apr 10]; 49(1):119-140. Available in: http://bibliotecadigital. 
fgv.br/ojs/index.php/rap/article/view/42967/0.

27. Souza AC. Parasiticidas Sintético e Natural em Bovinos: Escarabeíneos como Indicadores de Impactos Ambientais sobre Pastagens do Cerrado. [dissertação]. Lavras: Universidade Federal de Lavras. 2016. 67 p.

28. Rath S, Schroder CHK, Silva CR, et al. Avermectinas no agronegócio brasileiro: uma solução ou um problema? Vet. Zootec. 2016; 23(1):8-24.

29. Souza AP, Ramos CI, Belatto V, et al. Resistência de helmintos gastrintestinais de bovinos a anti-helmínticos no Planalto Catarinense. Cien. Rural. 2008; 38(5):1363-1367.

30. Dantas CCO, Silva LCRP, Mattos NF. Manejo sanitário de doenças do gado leiteiro. Pub.VET. 2010; 4:924930.

31. Silva T, Moreira J, Peres F. Serão os carrapaticidas agrotóxicos? Implicações na saúde e na percepção de riscos de trabalhadores da pecuária leiteira. Ciênc. Saúde Colet. [internet]. 2012 [accessed in 2018 Aug 10]; 17(2):311-325. Available in: http://dx.doi. org/10.1590/S1413-81232012000200006.

32. Carneiro FF, Rigotto RM, Augusto RGS, et al., organizadores. Dossiê ABRASCO um alerta sobre o impacto dos agrotóxicos na saúde: Saúde, Ambiente e Sustentabilidade. São Paulo: Expressão Popular; Escola Politécnica de Saúde Joaquim Venâncio; Fiocruz; 2015.

33. Martin JGP. Resíduos de antimicrobianos em leiteuma revisão. Segur. Aliment. Nutr. [internet]. 2011 [accessed in 2018 Sept 8]; 18(2):80-87. Available in: https//periodicos.sbu.unicamp.br/ojs/index.php/ san/article/view/8634680.

34. Souza MIA, Lage ME, Prado CS. Resíduos de antibióticos em carne bovina. 2013. Enciclopédia Bio. Cent. Cient. Conhecer. 9(16):1917-1938. Available in: https:// repositorio.bc.ufg.br/xmlui/handle/ri/13847.

35. Jones GM. On-farm tests for drug residues in milk. VCE Publications [internet]. 2009 [accessed in 2018
Oct 9]; (404):404-401. Available in: https://pubs.ext. vt.edu/404/404-401/404-401.html.

36. Tasho RP, Cho JY. Veterinary antibiotics in animal waste, its distribution in soil and uptake by plants: a review. Sci. Total Environ. [internet]. 2016 [accessed in 2018 Nov 11]; 1(563-564):366-376. Available in: https://www.ncbi.nlm.nih.gov/pubmed/27139307.

37. Olatoye IO, Ehinmowo AA. Oxytetracycline residues in edible tissues of cattle slaughtered in Akure, Nigeria. Nig. Vet. J. [internet]. 2010 [accessed in 2018 Dec 10]. 31(2):93-102. Available in: http://dx.doi. org/10.4314/nvj.v31i2.68952.

38. Borges JPR. Diagnóstico de situação do Plano Nacional de Controle de Resíduos e Contaminantes PNCRC/MAPA para a produção de suínos no Brasil em 2012. Brasília, DF: Universidade de Brasilia; 2013. Relatório.

39. Korb A, Brambilla DK, Teixeira DC, et al. Riscos para a saúde humana do uso de antibióticos na cadeia produtiva leiteira. Rev. Saúd. Pública [internet]. 2011 [accessed in 2018 Abr 25]; 4(1):21-36. Available in: http://revista.saude.sc.gov.br/index.php/inicio/ article/view/91.

40. Mehrotra M, Li XZ, Ireland MJ. Enhancing antimicrobial stewardship by strengthening the veterinary drug regulatory framework. Can. Commun. Dis. Rep. [internet]. 2017 [accessed in 2018 Apr 25]; 43(11):220223. Available in: https://europepmc.org/articles/ pmc5764736.

41. Pierini FG. Avaliação do uso de medicamentos veterinários e destinação de resíduos na microbacia do Mutum-APA do Rio Uberaba. [dissertação]. Ouro Preto: Universidade Federal de Ouro Preto. 2017. 84 p.

42. Mcconnell I. One Health in the context of medical and veterinary education. Revue Scientifique et Technique. [internet]. 2014 [accessed in 2018 Apr 25]; 33(2):651-657. Available in: https://pdfs.semanticscholar.org/3dc9/358eb6364a8e730a9ea4a2f51b6c9 3dad7ac.pdf. 
43. El-Hamamsy M. Unused Medications: How Cost and How Disposal of in Cairo, Egypt. Int. J. Pharm. Sci. Res. 2011; 2(1):21-27.

44. Sekyere J. Antibiotic types and handling practices in disease management among pig farms in Ashanti Region, Ghana. J. Vet. Med. [internet]. 2014 [accessed in 2018 Apr 26]. Available in: http://dx.doi. org/10.1155/2014/531952.

45. Instituto Brasileiro de Geografia e Estatística. Pesquisa Nacional de Saneamento Básico 2008. Brasília, DF: IBGE; 2010.

46. Carvalho FAH, Sá CR. A problemática dos resíduos farmacêuticos no Município de Rio Grande. Rev. Ciênc. Saúde [internet]. 2009 [accessed in 2018 May 5]; 21(1):59-72. Available in: https://periodicos.furg.br/ vittalle/article/view/1856.
47. Ueda J, Tavernaro R, Marostega V, et al. Impacto ambiental do descarte de fármacos e estudo da conscientização da população a respeito do problema. Rev. Cien. Amb. 2010; 5(1):1-6.

48. Hoppe TRG, Araujo LEB. Contaminação do meio ambiente pelo descarte inadequado de medicamentos vencidos ou não utilizados. Mon. Amb. 2012; 6(6):1248-1262.

Received on 04/28/2019

Approved on 09/23/2019

Conflict of interests: non-existent

Financial support: Ministry of Science, Technology, Innovation

and Communication (MCTIC), National Council for Scientific and

Technological Development (CNPq 441396/2017-8) e Research

and Innovation Support Foundation (Fapesc 2015TR1069) 